News, Notes and Queries

REFERENCES

1. TraIll, T. S., 'Memoir of Dr. T. C. Hope', Trans. Roy. Soc., Edin., 1848, 16, 419.

2. Coutrs, J., History of the University of Glasgow, Glasgow, Naclehose, 1909, p. 543.

3. Grant, SIR AleXANDER, The Story of the University of Edinburgh, London, Longmans, 1884, Vol. II, p. 398.

4. Life of Sir R. Christison by his Sons, Edinburgh, Blackwood, 1885-86, Vol. 1. p, 57.

5. MACKENZIE, J. E., 'The Chair of Chemistry in the University of Edinburgh in the XVIIIth and XIXth Centuries', J. Chem. Educ., 1935, 12, 503.

6. Roscob, H. E., and HARDen, A., A New View of the Origin of Dalton's Atomic Theory, London, Macmillan, 1896, p. 153.

7. Davy, J., The Collected Works of Sir H. Davy, London, 1839-40, Vol. 1, p. 83.

8. Kendall, J., in Kent, ANDREw, An Eighteenth Century Lectureship in Chemistry, Glasgow, Jackson, 1950, p. 157.

9. Hope, T. C., Trans. Roy. Soc., Edin. 1798, 4, 3.

10. Idem., Trans. Roy. Soc., Edin., 1798, 4, 34.

11. Idem., Trans. Roy. Soc., Edin., 1805, 5, 379.

12. Idem., Proc. Roy. Soc., Edin., 1845, 1, 126.

13. Idem., Proc. Roy. Soc., Edin., 1845, 1, 419.

14. Idem., Proc. Roy. Soc., Edin., 1845, 1, 429.

R. H. CRAGG

\title{
ORIGIN AND MEANING OF THE NAME 'CAROTIS'
}

THE terms carotis-arteria carotidea-sinus caroticus have long been established in anatomical nomenclature. I once asked myself what is the meaning and origin of the name 'carotis'? Why have the other arteries mostly a name related to the organ with which they are connected and why are the arteries in the neck called the 'carotid arteries'? As I did not know the answer to these questions, I had to investigate.

The first quotation concerning the function of the arteries in the neck of man appears in a publication of Aristotle (384-322 B.C.). ${ }^{1}$ In the translation of his Parva Naturalis it is stated 'also pressure on the veins (vessels) of the neck causes unconsciousness (fainting, sleep)'. It seems therefore that the term 'carotis' comes from the Greek word karos meaning 'soft, sleep' and was already used in anatomy before Aristotle.

This origin and meaning of the term 'carotis' was confirmed by Rufus of Ephesus (A.D. 98-117). In the French translation of the writings of Rufus' ${ }^{2}$ it is stated 'On a autrefois appliqué le nom d'assoupissants (carotides) aux vaisseaux qui montent à travers le cou, parce qu'en les comprimant on produit l'assoupissement et l'aphonie, mais on sait aujourd'hui que ces symptomes résultent de la compression des nerfs et non pas de celle des vaisseaux, de sorte qu'on ne ferait pas mal si on pensait devior changer ce nom'. In my opinion, the statement of Rufus is correct, because compression of the arteries in the neck of man does not induce sleep, but compression of the 


\section{News, Notes and Queries}

bifurcation of the carotid artery (carotid sinus) may provoke reflex bradycardia, fall of blood pressure and fainting. ${ }^{3}$ Hippocrates, Galen and Mattheus Curtius also observed that it was not the compression of the arteries in the neck, but of their bifurcation (carotid sinus) that might induce fainting or sleep. I therefore agree with the suggestion of Balourdas that if the old Greek physicians observed that compression of the arteries in the neck of man induced sleep, they did not perform compression of the arteries themselves but compressed the area of their bifurcation, the carotid sinus, and provoked a reflex fainting or sleep, in patients with a carotid sinus syndrome. The name 'carotis' has, therefore, its origin in the carotid sinus.

Andreas Vesalius gives, in his Fabrica the names of 'arteriae soporariae' or 'arteriae soporiferae' and not 'arteriae carotideae' to the arteries in the neck. Carolus Stephanus uses the terms 'arteriae apoplecticae', or 'arteriae lethargicae', or 'arteriae somni' and the Latin translations of the works of Arabian anatomists have the name 'arteriae subetini', originating from the Arabic word subtat (stupor, sleep). ${ }^{5}$

It seems therefore that the first observation that compression of the arteries in the neck of man provoked sleep must have been made in a patient with a carotid sinus syndrome in whom compression or stimulation of the baroreceptors of the carotid sinus area could have provoked fainting or sleep.

\section{REFERENCES}

1. Aristotle, Parva Naturalis. On Sleep and Awakening, tr. D. Ross, Chapter 2, 445b, 2-S. Oxford, Clarendon Press, 1955.

2. Rufus of Ephesus, Oeuvres, ed. by Ch. Daremberg and E. Ch. Reulie. Du non des parties du corps humain, p. 163, note 210, Amsterdam, Hakkert, 1963.

3. HeYmans, C., and NeI, E., Reflexogenic Areas of the Cardiovascular System, London, Churchill, 1958.

4. Balourdas, A., Proc. Med. Assoc. (Athens), 1941, p. 132; Med. Progr. (Athens), 1948, vol. 49.

5. HYRTL, J., Onomatologia Anatomica, p. 93 (Carotis), Wien, Braumüller, 1880.

\section{Greek Association of the History of Medicine}

We are pleased to record the reorganization of the Greek Association of the History of Medicine, first established in 1927, under the presidency of Professor N. K. Louros with Associate Professor G. C. Pournaropoulos as General Secretary. Professor Louros is Director of the University of Athens 'Alexandra' Hospital, Member of the Greek Academy and the Council of Health. He received his medical training in the universities of Athens, Vienna, Munich, Berlin and Bern and is a specialist in obstetrics and gynaecology and child health. He was awarded a prize by the Institute of France for his scientific work and is a Member of the Academia Leopoldina. Dr. Pournaropoulos, who was educated at the University of Athens and the Institute of 